\title{
Monika Stankiewicz-Kopeć
}

http://orcid.org/0000-0003-1650-3887

Akademia Ignatianum w Krakowie

monikastan-kopec@wp.pl

DOI: 10.35765/pk.2021.3403.06

\section{Wzór osobowy kobiety polskiej okresu niewoli politycznej. Wokół Pamiattki po dobrej matce Klementyny z Tańskich-Hoffmanowej}

\section{STRESZCZENIE}

Celem niniejszego artykułu jest przypomnienie jednego z ważniejszych (acz zapomnianych) kobiecych wzorów osobowych popularnych w kulturze polskiej czasów zaborów, rozpropagowanego w 1819 r. przez młodą warszawską pisarkę Klementynę Tańską (później Hoffmanową) w jej powieści-poradniku dla dziewcząt i młodych mężatek pt. Pamiątka po dobrej matce. Na poglądy autorki tego bestselleru sprzed dwóch wieków należy patrzeć w perspektywie historycznej, w ścisłym połączeniu z szerokim kontekstem dziewiętnastowiecznym (dziejowym, społecznym, prawnym, kulturowym), biorąc pod uwagę trudną i złożoną sytuację społeczeństwa polskiego w okresie niewoli politycznej oraz uświadomioną już w pierwszych latach zaborów potrzebę ochrony tożsamości narodowej. Tę właśnie swoistą misję dziejową Klementyna z Tańskich przypisała polskim kobietom jako żonom, matkom i obywatelkom: kobietom odpowiednio ukształtowanym moralnie i wykształconym adekwatnie do ówczesnych możliwości i potrzeb.

Chociaż jej program zawierał pewne elementy nowatorskie, to celowo był on bardzo ostrożny i tradycyjny, akceptujący aktualne regulacje i ograniczenia prawne oraz wskazania wynikające z religii chrześcijańskiej, jak również polskie obyczaje i przyzwyczajenia społeczne (m.in. patriarchalizm). Autorka posiadała bowiem świadomość, że tylko tego rodzaju program miał szansę zostać zaakceptowany społecznie i zrealizowany w tamtym czasie.

Propagowanie przez Tańską ściśle określonego wzoru kobiety Polki było jej świadomym wyborem dokonanym w perspektywie społecznej. Sama Klementyna Tańska w istocie prezentowała już bowiem zdecydowanie nowy typ kobiety: wolnej (wyszła za mąż dopiero w wieku 31 lat, nie miała dzieci), wykształconej, aktywnej zawodowo, zainteresowanej sprawami publicznymi, samodzielnej, niezależnej finansowo (dzięki własnej pracy), przedsiębiorczej (a przy tym głęboko religijnej, zdeklarowanej patriotki). Patrząc jednak na propagowany przez nią wzór kobiety i model kobiecości, widać, że nie 
wszystkie z wyżej wymienionych cech autorka Pamiątki po dobrej matce uważała za pożądane dla ogółu polskich kobiet. Toteż pozostawiła je dla siebie.

Natomiast dla ogółu Polek czasów niewoli Klementyna z Tańskich Hoffmanowa stworzyła i spopularyzowała inny, zdecydowanie bardziej tradycyjny wzór kobiety: realizującej się przede wszystkim na płaszczyźnie domowo-rodzinnej, zapobiegliwej gospodyni, oddanej żony, matki, świadomej obywatelki - wychowującej dzieci w duchu narodowym. W jej przekonaniu taki bowiem był najbardziej pożyteczny, a przy tym akceptowalny społecznie wzór osobowy polskiej kobiety na trudne czasy niewoli politycznej.

SŁOWA KLUCZE: kobieta, zabory, wiek XIX, Polska, wzór osobowy, poradnik, Klementyna z Tańskich Hoffmanowa

\section{AB STRACT}

Personal Model of the Polish Woman During the Political Enslavement Period. Around Pamiatka po dobrej matce by Klementyna Tańska-Hoffman

The aim of this article is to recollect a central (albeit forgotten) female role model popular in Polish culture during the Partitions of Poland, popularized in 1819 by a young Warsaw writer, Klementyna Tańska (married name: Hoffman), in her novel-guidebook for girls and young married women entitled Pamiatka po dobrej matce (A Souvenir from a Good Mother). The opinions of the bestseller author from two centuries ago should be viewed from a historical perspective, in close connection with their broad nineteenth-century context (historical, social, legal, cultural), taking into account the difficult and complex situation of Polish society during the period of political enslavement and the need, already recognized in the first years of the partitions, to protect national identity. Klementyna Tańska attributed this particular historical mission to Polish women, as wives, mothers, and citizens: women who were morally developed and educated in accordance with the possibilities and needs of the time.

Although her plan contained some innovative elements, it was deliberately very cautious and traditional, accepting current legal regulations, restrictions and indications resulting from the Christian religion, as well as Polish social customs and patterns (e.g. patriarchy). The author was aware that only this kind of program had a chance of being socially accepted and implemented at that time.

Tańska's promotion of a strictly defined model of a Polish woman was her conscious choice she made from a social perspective. In fact, Klementyna Tańska herself already represented a decidedly new type of woman: free (she did not marry until the age of 31 and had no children), educated, professionally active, interested in public affairs, independent, also financially (thanks to her own work), and enterprising (while at the same time deeply religious and a declared patriot). However, looking at the model of a woman and the model of femininity she propagated, the author of Pamiatka po dobrej matce did not 
include all the above-mentioned features as desired for Polish women in general. Thus, she adopted them for herself only.

Hoffman, née Tańska, created and popularized a different, definitely more traditional model of a woman for all Polish women in the times of enslavement: a woman who sought fulfillment first and foremost at the level of the home and family, as a frugal housewife, a devoted wife, a mother, and a conscious citizen raising her children in the national spirit. She believed that this was the most practical, and at the same time, a socially acceptable model of a Polish woman for the difficult times of the political enslavement.

KEYWORD S : women, partitions, 19th century, Poland, personal model, guidebook, Klementyna Hoffman née Tańska

Każda trwała zbiorowość narzuca swym członkom (...) wzory zachowania się w różnych okolicznościach, reguły moralne i poczucie tego, co przyzwoite, a co niestosowne, narzuca pewne poglądy i sposoby myślenia. Narzuca je bądź świadomie, za pomocą metod wychowawczych i propagandy, za pomocą oznak aprobaty lub nagany, niekiedy nawet przy użyciu środków zewnętrznego przymusu, bądź nieświadomie, przez sam fakt zbiorowego stosowania się do owych wzorów i regul. Ogół tych wzorów stanowi o swoistej kulturze takiej zbiorowości, a pewien ich zespół składa się na panujący w tej grupie wzór osobowy (Ossowski, 2000, s. 50).

\section{Wstęp}

24 października 1795 r. po podpisaniu traktatu rozbiorowego Rzeczypospolita Polska, podzielona pomiędzy Rosję, Prusy i Austrię, przestała istnieć jako państwo niezależne i niepodległe na 123 lata. Podkreślając wyjątkowość tego wydarzenia w skali całej ówczesnej Europy, historycy polscy zwracają uwagę:

Znikło już było z mapy Europy kilka państw, żadne jednak nie na taką skalę, tak dramatycznie i na takiej zasadzie. Wyjątkowe w 1795 roku było to, że zabór terytorialny oznaczał likwidację formalnie suwerennego państwa i że nie wynikało to z jakichkolwiek praw dziedzicznych zwycięskich władców. Trzeci rozbiór można traktować jako ewenement w dziejach Europy XVI-XVII w., nie tylko z racji znaczenia Rzeczypospolitej w mijającej epoce, ale i dla jej szczególnego charakteru, była to realpolitik bez pozoru nawet dynastycznych praw własności (Mączak, 1993, s. 123). 
Nowa rzeczywistość, w jakiej znaleźli się Polacy po trzecim rozbiorze, bez precedensu w dotychczasowych dziejach Rzeczypospolitej, z czasem przyniosła wiele istotnych zmian w rozmaitych obszarach życia społeczno-polityczno-kulturalnego (zob. m.in. Zdrada, 2005; Chwalba, 2008).

Okresem szczególnie ważnym dla Polaków w tym względzie były trzy pierwsze dekady zaborów (od 1795 do 1830 r., czyli do wybuchu powstania listopadowego). Ówcześni mieszkańcy ziem polskich, doświadczając nowej sytuacji i jej wielowymiarowych skutków, zmuszeni zostali bowiem do ustosunkowania się do zachodzących bezprecedensowych zmian, a także do wypracowania strategii trwania i przetrwania w najbliższych latach i dekadach ${ }^{1}$. Jednym z elementów wspomnianej strategii było wykształcenie i spopularyzowanie w kulturze polskiej nowych wzorów osobowych adekwatnych do czasów niewoli politycznej: wzorów wzmacniających tożsamość narodową, integrujących społeczeństwo polskie.

\section{Polska po roku 1795 - pierwsze dekady zaborów}

Po początkowym szoku Polaków po trzecim rozbiorze Rzeczypospolitej i związanej z tym zapaści społecznej (kiedy „organizm całego społeczeństwa wyczerpany długą, konwulsyjną agonią, wpadł w stan obumarcia”) ${ }^{2}$ już niebawem polskie elity, poddając refleksji trudną sytuację, w jakiej znalazł się naród (zarówno na skutek własnych wieloletnich błędów i zaniedbań, jak i aspiracji mocarstwowych swoich sąsiadów), zaczęły zastanawiać się nad sposobami z jednej strony „wybicia się na niepodległość”, zaś z drugiej przetrwania w sytuacji zniewolenia (jako naród), tak aby nie zatracić tożsamości narodowej na wypadek, gdyby w najbliższym czasie nie udało się odzyskać niezależności politycznej (co zdawały się potwierdzać kolejne lata i dekady) (por. Jedlicki, 2002, s. 14).

Najpierw podjęto aktywność niepodległościową, stając do walki z bronią w ręku. Jeszcze bowiem nie ucichły echa insurekcji kościuszkowskiej (1794), a już na obczyźnie z inicjatywy generała Jana Henryka Dąbrowskiego zostały powołane Legiony Polskie (1797), formacje wojskowe posiłkujące Republikę Lombardii utworzoną przez Napoleona

1 W niniejszym artykule nawiązuję do ustaleń poczynionych wcześniej w następujących pracach: Stankiewicz-Kopeć, 2016, s. 99 i n.; Stankiewicz-Kopeć, 2018, s. 329 i n. W tekście znalazły się sformułowania pochodzące z ww. prac, jak również inspiracje bibliograficzne.

2 Zob. Dębicki, 1887, s. 3-4: „Po pogromie maciejowickim, zdobyciu Warszawy, rzezi na Pradze, wywiezieniu króla do Grodna i ostatnim rozbiorze - rozpacz ogarniała jednostki, były liczne wypadki samobójstw, wielu postradało zmysły, inni wpadali w dziwactwa, szukali zapomnienia w ekscentrycznościach, inni w wirze światowych zabaw”. 
Bonaparte, z którym Polacy wiązali nadzieje na odzyskanie niepodległości (zob. m.in. Kukiel, 1912; Askenazy, 1918). Po klęsce Napoleona i kongresie wiedeńskim (1815) następnymi etapami owej militarnej aktywności niepodległościowej Polaków stały się kolejne powstania narodowe: listopadowe (1830/31) i styczniowe (1863/64) (zob. Kieniewicz, Zahorski i Zajewski, 1992).

Jednak w gruncie rzeczy już w pierwszych latach XIX w. Polacy zaczęli zdawać sobie sprawę (i to coraz boleśniej wraz z upływem kolejnych dekad), iż odzyskanie niepodległości będzie procesem długotrwałym, obliczonym na kolejne dekady. Rychło pojęli także, iż walczyć z bronią w ręku nie można przecież bezustannie, zaś dla wzmocnienia sił narodowych niezbędna jest permanentna i stała praca organiczna. Szczególnym wyrazem tego rodzaju przekonań był „testament” generała Jana Henryka Dąbrowskiego z 1818 r., zwracającego uwagę na konieczność budowania sily cywilizacyjnej ziem polskich oraz na potrzebę „nieustannej pracy ku przysparzaniu moralnych i materialnych zasobów" ${ }^{3}$. Toteż niebawem obok działań niepodległościowych o charakterze zbrojnym nastąpiła również swoista „mobilizacja” aktywności sił narodowych połączona z próbami zaadaptowania się do nowych warunków.

Wspomnianą łatwość adaptacji pewnej części elit społeczeństwa polskiego do nowych warunków politycznych (przed 1830 r.) niektórzy współcześni historycy polscy próbują tłumaczyć, używając metafory „dwóch sumień”, czego skutkiem miało być podporządkowanie postępowania i wyborów czynionych w życiu społeczno-politycznym celowi nadrzędnemu, jakim było utrzymanie tożsamości narodowej (zob. Czubaty, 2005, s. 665-668). Szczególnie dobrze widoczne stało się to po roku 1815. W tym czasie (po klęsce Napoleona) wraz z utworzeniem Królestwa Polskiego na czele z carem Aleksandrem I, jako jego królem, rozpowszechniała się polska jasna legenda cara Aleksandra I jako twórcy nowej Ojczyzny, dawcy liberalnej konstytucji - „dobroczyńcy” i „Anioła pocieszyciela" Polaków ${ }^{4}$.

Już w pierwszych latach XIX stulecia wypracowany został przez elity polskie szeroki program modernizacyjny odnoszący się do kilku najważniejszych obszarów życia społecznego, takich m.in. jak nauka, kultura, edukacja, wychowanie. W kolejnych dekadach zaowocował on swoistą rekonstrukcją instytucjonalną przebiegającą w kilku fazach (związanych z sytuacją polityczną ziem polskich) w głównych ośrodkach leżących na

3 Słowa gen. J.H. Dąbrowskiego, cyt. za: Zamorski, 1881, s. 55-56.

4 Zob. Koźmian, 1972, s. 59. Oczywiście, istniał też drugi negatywny biegun owej legendy, spopularyzowany przede wszystkim po 1830 r. przez największych polskich poetów romantycznych: Adama Mickiewicza (Dziady, cz. III) i Juliusza Słowackiego (Kordian). 
terenie dawnej Rzeczypospolitej. Przypomnijmy, przed 1830 r. nastąpiło m.in.: powołanie warszawskiego Królewskiego Towarzystwa Przyjaciół Nauk (1800) oraz rozwój szkół i uniwersytetów na ziemiach polskich. Przykładowo: za zgodą cara Aleksandra I w roku 1803 r. wznowiła aktywność uczelnia wileńska jako Cesarski Uniwersytet Wileński (1803), w stolicy Królestwa Kongresowego powstał Królewski Uniwersytet Warszawski (założony w 1816 r.). W roku 1805 w Krzemieńcu powołano do istnienia prestiżowe Gimnazjum Wołyńskie - od 1819 r. funkcjonujące jako Liceum Krzemienieckie (Suchodolski, 1977, s. VII i n.). W tym czasie rozwijało się także szkolnictwo innego rodzaju, powstały m.in.: Szkoła Górnicza w Kielcach (1816), Szkoła Leśnictwa w Warszawie (1818), Instytut Agronomiczny w Marymoncie (1820), Szkoła Przygotowawcza do Instytutu Politechnicznego (1826) (zob. Miąso, 1966, s. 28-42).

W pierwszych dekadach XIX stulecia (przed 1830 r.) na pozostających pod zaborami ziemiach polskich nastąpiło także swoiste ożywienie intelektualne i kulturalne, zaś kultura polska weszła w krąg nowych tematów i problemów inspirujących od tego czasu polskie piśmiennictwo w imię naczelnej idei podtrzymania tożsamości narodowej. Jednym z tych ważnych społecznie tematów były nowe wzory osobowe (męskie i kobiece) adekwatne do okresu niewoli politycznej.

\section{Wokół wzorów osobowych}

Dla porządku przypomnijmy: wzór osobowy to „zespół wartości” ceniony i pożądany przez członków społeczeństwa, to określony „zestaw cech”, których posiadanie sprawia, że człowiek cieszy się szacunkiem i uznaniem społecznym (Ossowska, 1992, s. 9-41). Wzór osobowy stanowi najwyższy cel wychowania, związanego z oddziaływaniem moralnym osoby, której cechy albo czyny uważa się za godne naśladowania (por. Rynio, 2015, s. 1459-1465). Należy zaznaczyć, iż chociaż w obiegu potocznym pojęcie „wzoru osobowego” często jest kojarzone z pojęciami „wzorca” czy „ideału”, to jednak w istocie nie są one tożsame. Wzór osobowy stanowi bowiem swoiste ucieleśnienie abstrakcyjnego wzorca mającego charakter normatywny - jest jego spersonalizowaną egzemplifikacją (por. Ossowska, 2000, s. 8-11). Przy tym wzory osobowe zmieniają się w zależności od czasu i przestrzeni, podlegają bowiem weryfikacji historycznej, w przeciwieństwie do ponadczasowych wzorców stanowiących o obiektywnym ładunku aksjologicznym (por. Świderska-Włodarczyk, 2016, b.n.s). $\mathrm{W}$ socjologii pojęcie wzoru osobowego współistnieje natomiast z pojęciem wzoru kulturowego (także charakteryzującego się zmiennością) pojmowanego jako określony standard osobowy (wzór osobowy), etyczny, 
obyczajowy, estetyczny uznany za godny naśladowania w danej społeczności (por. Wysocka, 2008, s. 628).

Wzorem osobowym może być zarówno postać realna, jak i fikcyjna (jako nosiciel określonych cech i wartości) stanowiąca przedmiot aspiracji członków danej grupy społecznej, na którym modeluje się kultura określonej społeczności. Należy podkreślić, że w jednej zbiorowości w tym samym czasie może funkcjonować jednocześnie kilka lub kilkanaście wzorów osobowych, charakterystycznych np. dla danej grupy społecznej, wiekowej, zawodowej czy w odniesieniu do przedstawicieli konkretnej płci (wzory kobiece i wzory męskie). Tak było również na ziemiach polskich w pierwszych dekadach zaborów.

Wzory osobowe (oraz związane z nimi tzw. antywzory) stanowią o odrębności i swoistości danej kultury. Propagowane w danym społeczeństwie kształtują bowiem pożądane społecznie postawy i wartości, w ten sposób podtrzymując ład społeczny. Oczywiście, wzory osobowe odgrywają także nieocenioną rolę w integracji społecznej i narodowej, co było szczególnie ważne dla Polaków w okresie zaborów, oraz mają istotne znaczenie w przygotowaniu młodego pokolenia do pełnienia określonych ról społecznych. Ról mocno związanych z aktualnymi realiami społecznymi, politycznymi, kulturowymi - tak jak było na ziemiach Rzeczypospolitej właśnie po roku 1795.

W pierwszym trzydziestoleciu XIX stulecia na ziemiach polskich współistniały (i nakładały się na siebie) rozmaite wzory osobowe, charakterystyczne dla określonych środowisk - wzory męskie i kobiece. Przy czym tworzenie się nowych wzorów osobowych w pierwszych dekadach zaborów na ogół nie następowało poprzez radykalne odcięcie się od tych ubiegłowiecznych, ale raczej poprzez inspirację, przenikanie czy różnicowanie (w kontekście nowej sytuacji). Wśród wzorów męskich był to m.in.: wzór obywatela - gospodarnego ziemianina zainteresowanego dobrem Ojczyzny - inspirowany dawnymi ideałami staropolskimi; wzór patrioty walczącego o niepodległość Ojczyzny i oddającego dla niej swoje życie spopularyzowany w sposób szczególny przez polską literaturę romantyczną (1822-1864). Na początku XIX w. w tym czasie w związku z nowymi realiami politycznymi oraz związanymi z nimi przemianami prawnymi i społecznymi kształtował się również wzór inteligenta (m.in. urzędnika). Ówcześnie podejmowano także próby (na razie jeszcze pojedyncze) wprowadzenia pozytywnego wzoru polskiego bohatera przedsiębiorczego, robiącego karierę finansową. Na ziemiach polskich w pierwszej połowie wieku XIX do kwestii tej podchodzono jednak jeszcze bardzo ostrożnie i z dużą rezerwą (inaczej niż na Zachodzie, np. na terenie Niemiec).

Odnosząc się do tego problemu, historyk Janusz Tazbir pisał nawet o swoistej „pochwale «nieudacznika» i naganie kariery” w ówczesnej 
kulturze polskiej (Tazbir, 1979, s. 239 i n.). Chociaż trudno odmówić trafności wielu wnioskom historyka, to jednak nie można zgodzić się na upraszczające sprowadzenie problemu do owej tytułowej „pochwały «nieudacznika» i nagany kariery”, bowiem:

Ów polski „nieudacznik” (a przynajmniej wielu ówczesnych „nieudaczników”) (...), żyjąc w określonej sytuacji historycznej naznaczonej kolejnymi powstańczymi zrywami, raczej nie miał większych szans na to, aby działać w taki sam sposób, jak jego przedsiębiorczy zachodnioeuropejscy rówieśnicy, wykorzystujący długotrwały pokongresowy pokój (jaki zapanował na zachodzie Europy, przerywany jedynie lokalnymi konfliktami) do podejmowania wielkich interesów i tworzenia imponujących burżuazyjnych fortun (...). Trudność wykreowania tego rodzaju bohatera wiązała się także z brakiem powszechnej aprobaty dla wartości, które miałby on sobą reprezentować 5 .

W trzech początkowych dekadach zaborów także w odniesieniu do kobiecych wzorów osobowych funkcjonujących na ziemiach polskich panowała znaczna różnorodność. Nie istniał bowiem ówcześnie jednolity wzór kobiety w odniesieniu do różnych grup społecznych.

Wśród szlachty prowincjonalnej przeważa bądź model zacnej staroświeckiej matrony, bądź wzór rządnej i żwawej gospodyni, szafarki obfitości. W kulturze klas średnich następuje starcie i przewartościowanie norm oraz wymogów zaczerpniętych z różnych wzorców i tradycji. Rozmaitość wzorców i postulatów jest tu ogromna: od czułej i anielskiej, cnotliwej i skromnej (z Richardsona) do egzaltowanej i tajemniczej, poetycznej i niezrozumianej, demonicznej i niszczycielskiej (z powieści francuskiej); od damy, kokietki, lwicy, romansowej heroiny do patriotki i moralistki; od pracowitej służebnicy ludu do bezczynnej, luksusowej damy; od szatana i wampa do mistyczki, poetki, druidessy, wieszczki, powierniczki poetów; od matki-Polki do „dziewicy-bohatera (...). Niemniej można określić sfery rzeczywistości, jakie oddane zostały pod niepodzielne panowanie kobiet: ognisko domowe, życie rodzinne i świat kultury duchowej i piękna. Te zakresy działania określały zespół ról społecznych wyznaczonych kobiecie (Kamionkowa, 1970, s. 81).

Do owych „sfer rzeczywistości” należałoby dodać jeszcze szeroko rozumianą sferę narodową, uobecniającą się zarówno w życiu domowo-rodzinnym, jak i coraz częściej także w sferze obywatelskiej, co jest

5 Pisałam na ten temat w pracy: Stankiewicz-Kopeć, 2018, s. 442 (szerzej na temat różnorodności ówczesnych wzorów osobowych na stronach: 321-494). 
szczególnie ważne w odniesieniu do bohaterki niniejszego artykułu Klementyny z Tańskich Hoffmanowej.

\section{Pamiątka po dobrej matce czyli jej ostatnie rady dla córki: powieść-poradnik Klementyny z Tańskich}

Bez wątpienia jednym z najważniejszych kobiecych wzorów osobowych wykształconych i upowszechnianych na ziemiach polskich w pierwszych dekadach niewoli był wzór kobiety Polki - żony, matki i obywatelki rozpropagowany przez dwudziestojednoletnią warszawiankę Klementynę z Tańskich późniejszą Hoffmanową (1798-1845) w jej dydaktycznej powieści dla dziewcząt pt. Pamiątka po dobrej matce czyli jej ostatnie rady dla córki (wyd. Warszawa 1819) ${ }^{6}$. Chociaż dzieło Tańskiej miało niemiecki protestancki pierwowzór autorstwa luterańskiego pastora Jacoba Glatza (był nim Testament Rozalii dla jej córki Amandy [Glatz, 1808]), to jednak podstawowe idee wychowawcze obu utworów były różne. Dzieło luterańskiego pastora dla młodej autorki stało się przede wszystkim „podnietą do sformułowania własnych przekonań” (por. Kotowa, 1925/26, s. 202-220). Tańska dostosowała bowiem swoją powieść do polskich warunków oraz oczekiwań polskich czytelników, a także złagodziła protestancką wymowę utworu Glatza.

Sama autorka Pamiatki po dobrej matce, Klementyna Tańska, była osobą zaangażowaną społecznie oraz aktywną zawodowo. W okresie warszawskim (do 1831 r.) pracowała jako wydawca, m.in. wydawała pierwsze na ziemiach polskich pismo periodyczne dla dzieci „Rozrywki dla dzieci” 1824-1828 (por. Libera, 1982, s. 5-16), współpracowała z firmą wydawniczo-drukarską „A. Gałęzowski i Spółka”, była też wizytatorką (eforką) pensji żeńskich, nauczycielką - od 1826 r. wykładała naukę moralną i obyczajową w warszawskim Instytucie Rządowym Wychowania Płci Zeńskiej (nazywanym Instytutem Guwernantek) oraz na związanej z nim Pensji Wzorowej. W uznaniu jej zasług Feliks Bentkowski i hrabia Fryderyk Skarbek w roku 1826 zgłosili wniosek przyjęcia Tańskiej (jako pierwszej kobiety) w szeregi warszawskiego Towarzystwa Przyjaciół Nauk. Kandydaturę Tańskiej odrzucono jednak w roku $1827^{7}$. Natomiast na początku roku 1828 Klementyna z Tańskich została mianowana wizytatorem wszystkich szkół i pensji dla dziewcząt w Warszawie. W okresie powstania listopadowego Tańska (od roku 1829 Hoffmanowa) zajmowała

6 W roku 1819 utwór miał też drugie wydanie; potem przyszły kolejne, np. 1820, 1824 i następne.

7 Co motywowano następująco: „ustawy nie wspominają o tym czy niewiasty do towarzystwa przystęp mieć mogą”, zaś jak twierdzono ,przemilczenia ustaw w tym przedmiocie za przyzwolenie uznać nie można”. Por. Kraushar, 1901. 
się działalnością patriotyczno-filantropijną (m.in. była współtwórczynią Związku Dobroczynności Patriotycznej Warszawianek, pracowała w lazaretach), zaś po wyjeździe z kraju (po upadku powstania listopadowego) działała w środowisku emigracyjnym w Paryżu (była pierwszą sekretarką i autorką ustaw Towarzystwa Dobroczynności Dam Polskich) (zob. m.in. Chmielowski, 1898; Chmielowski, 1901, s. 170-172; Ciechanowska, 1960-1961, s. 573-576; Dąbrowska, 2008).

Wydając swoją powieść prawie ćwierć wieku po wymazaniu państwa polskiego z mapy świata, w czwartym roku istnienia Królestwa Polskiego, młoda autorka, która nie wierzyła ani w trwałość tego nowego bytu politycznego powołanego na kongresie wiedeńskim, ani w długoterminową dobroć cara Aleksandra I w stosunku do Polaków, za swoją misję uznała podjęcie najpilniejszych działań o charakterze „obronnym”, mających na celu wzmocnienie tożsamości narodowej poprzez zreformowanie wychowania polskich kobiet jako żon i matek kolejnych pokoleń rodaków.

Klementyna Tańska była przekonana, że aby Polki w pełni mogły sprostać swoim zadaniom, konieczna jest ich „odnowa moralna” w duchu narodowym. Do realizacji swego celu autorka wybrała jej zdaniem najskuteczniejsze narzędzie. Nie traktat teoretyczny, nie poważną naukową rozprawę, którą przeczytają tylko nieliczni, ale utwór fabularyzowany w postaci dydaktycznej powieści-poradnika dla dziewcząt, mający szansę trafić jeśli już nie pod „strzechy”, to pod dachy szlacheckich dworów oraz do domów inteligenckich i mieszczańskich. Powieść Pamiątka po dobrej matce została bowiem pomyślana przez młodą autorkę jako zapis szczegółowych rad kierowanych do nastoletniej córki Amelii przez umierającą matkę, która jej przyszłym dorosłym życiem pragnęła pokierować tak, aby było ono szczęśliwe, spełnione i pożyteczne narodowo.

Współcześnie Pamiątka po dobrej matce jest utworem znanym jedynie garstce historyków polskiej literatury i edukacji, dziełem traktowanym jako anachroniczne. Powieść Tańskiej warta jest jednak przywrócenia pamięci jako swoisty dokument epoki - dokument świadomości narodowej w epoce zagrożenia ${ }^{8}$. Przy tym jest to dokument niebagatelnej wagi, już choćby z tego względu, iż propagowany tam wzór kobiety stał się w pierwszej połowie wieku XIX niezwykle popularny na ziemiach polskich. Po wydaniu w roku 1819 powieść Tańskiej zyskała bowiem uznanie krytyków (por. m.in. Brodziński, 1819), a także:

8 Zamieszczony w Pamiątce po dobrej matce program wychowania dziewcząt był rozwijany w kolejnych utworach Klementyny z Tańskich, m.in. w Listach matki o wychowaniu córek swoich („Rozrywki dla Dzieci” 1824-1826), w powieści Amelia matka. Dzieto za dalszy ciagg „Pamiątki po dobrej matce” stużć mogące, przez tęż samą Autorkę (Warszawa 1822-1822, t. 1-3), a zwłaszcza w rozprawie O powinnościach kobiet (Berlin 1849). 
(...) szturmem zdobyła polską publiczność. Ani przedtem oczywiście, ani potem już nigdy żadne poważne dzieło autorki polskiej nie mogło się pochwalić takim sukcesem, taką szeroką popularnością, i tak głębokim wpływem na swoje społeczeństwo (Kotowa, 1925/26, s. 203).

Pamiątka po dobrej matce Tańskiej od czasów swojego wydania do połowy wieku XIX była więc swoistym bestsellerem - utworem wielokrotnie wznawianym, tłumaczonym na języki obce (m.in. francuski, niemiecki), adaptowanym na różne sposoby, stanowiącym inspirację dla innych literackich „traktatów” pedagogicznych (w tym dla traktatu czeskiego Honoraty z Wiśniowskich Zapovej Niezapominajki, dar dla naszych panien, 1849). W 1827 r. w Sankt-Petersburgu ukazała się także rosyjska adaptacja Pamiatki po dobrej matce, przetłumaczona przez Jewgieniię Markianowicz z dedykacją dla cesarzowej Aleksandry Fiodorowny. Książka zatytułowana Pamjat' dobroj materi, ili Poslednie eja sovety docheri svoej była:

(...) przystosowana do odczytania utworu w kontekście kultury rosyjskiej. W tym czasie w literaturze rosyjskiej (i nie tylko w niej) brakowało bowiem utworów edukacyjnych poświęconych wychowaniu płci pięknej, dlatego przeróbka z języka polskiego uzyskała pochlebne opinie rosyjskich krytyków (Guseva, 2019, s. 22).

Wracając do polskiej recepcji dzieła Tańskiej, należy zaznaczyć, że zaproponowany na kartach Pamiątki po dobrej matce wzór kobiety Polki oraz związany z nim swoisty program wychowawczo-edukacyjny zyskał możliwość szczególnie szerokiej recepcji, zwłaszcza na terenie Królestwa Polskiego, od czasu kiedy Komisja Rządowa Wyznań Religijnych i Oświecenia Publicznego włączyła tę powieść w poczet lektur przeznaczonych do użytku wszystkich pensji i szkół żeńskich, co znacznie zwiększyło jego zakres i moc oddziaływania społecznego. W efekcie powieść Tańskiej stała się dziełem o ogromnym znaczeniu społecznym - jednym z czołowych ówczesnych polskich utworów „wzorotwórczych”.

Wzór kobiety wpisany w powieść Tańskiej, obok cech uniwersalnych, w związku z inspiracjami autorki bogatą literaturą przedmiotu (głównie francuską końca XVIII i początku XIX w. ${ }^{9}$ ), co pozwalało mu na

9 Między innymi dziełami pań: de Lambert, de Genlis, de Beaumont, de Sévigné, a także utworami Fénelona i Rousseau. 
zaistnienie także poza polskim obszarem kulturowym, posiadał jednak bardzo wyraźne cechy wzoru okolicznościowego i lokalnego związanego z polskimi realiami pierwszych dekad zaborów, a także z polskimi tradycjami wychowawczymi (por. Dąbrowska, 2008, s. 85).

Swoją powieścią dydaktyczną młoda autorka włączyła się w debatę nad problemem kształcenia i wychowania Polek, sięgającą korzeniami do drugiej połowy XVIII stulecia, m.in. w związku z aktywnością Komisji Edukacji Narodowej. Do problemu nauczania kobiet powracano raz po raz w kolejnych dekadach (np. w okresie Księstwa Warszawskiego, a potem w czasach Królestwa Polskiego). Namysł nad edukacją i wychowaniem zarówno polskich mężczyzn, jak i kobiet stał się bowiem niezwykle ważny zwłaszcza w czasach niewoli politycznej, kiedy kwestię edukacji wiązano z koniecznością podtrzymania tożsamości narodowej oraz z zagadnieniem trwania i przetrwania narodu bez państwa (Winiarz, 2002). Tymczasem ówczesny model kształcenia kobiet, głównie tych wywodzących się z warstw wyższych, nadal nastawiony był głównie na potrzeby konwencjonalnego życia towarzysko-salonowego, którego bazę stanowił język i kultura francuska. W czasie kiedy Tańska wydawała swoją powieść, wciąż więc jeszcze bardzo dużo było w tym zakresie do zrobienia ${ }^{10}$.

W tym miejscu należy podkreślić, że Pamiątka po dobrej matce nie propagowała wzorów zupełnie nowych. Chociaż bowiem zaproponowany przez Tańską model wychowawczo-edukacyjny kobiety (oraz związany z nim wzór osobowy Polki) miał pewne elementy, które można uznać za nowatorskie, np. autorka proponowała nowoczesny model rodziny (wzorując się na Rousseau) opierający się na wzajemnej przyjaźni i serdeczności, eksponowała potrzebę samodzielności w wyborze małżonka, podkreślała konieczność i wartość kształcenia kobiet, podejmowania przez nie pracy zawodowej, zwracała uwage na społeczno-narodowe znaczenie kobiet (jako matek kolejnych pokoleń Polaków), to jednak w gruncie rzeczy był to model mocno osadzony w polskiej tradycji. Przy tym był to model celowo niekontrowersyjny, kompromisowy, starający się godzić stare tendencje (przedzaborowe) i nowe wymagania (okresu zaborów).

\section{Wzór kobiety Polki na „trudne czasy”}

Podstawowym celem Klementyny Tańskiej jako autorki Pamiątki po dobrej matce było odpowiednie wychowanie Polek, czyli takie ukształtowanie ich charakteru oraz wyrobienie ich „poglądu na świat”, aby w przyszłości (już

10 O edukacji polskich kobiet w pierwszej połowie wieku XIX oraz o ich roli w rodzinie por. m.in. Żołądź-Strzelczyk, 2001; Bołdyrew, 2008; Winiarz, 2000, s. 146 i n. 
jako żony, matki, obywatelki) stały się swoistymi strażniczkami narodowości: strażniczkami polskich rodzin i domów. W tym kontekście w refleksji Tańskiej dom i rodzina urastały do rangi kategorii nadrzędnych, kumulujących takie wartości, jak m.in.: narodowość, religijność, swojskość. Było to zresztą jedną z ważniejszych cech kultury polskiej czasów zaborów (zob. Mickiewicz, 1952, s. 63-64) ${ }^{11}$. Utrata przez Polskę państwowości spowodowała bowiem, że obowiązek wychowania dzieci urósł do rangi sprawy politycznej, z tego względu, że rodzina stała się jedynym gwarantem utrzymania tożsamości narodowej. Polscy badacze słusznie zwracają uwagę, że wszystko to doprowadziło do wykreowania w okresie utraty niepodległości i państwowości:

(...) kulturowego wzorca kobiety polskiej jako postaci heroicznej, zdolnej sprostać wszelkiego typu wyzwaniom. Według tradycji religijnej, żądano od płci żeńskiej gotowości do ofiar i poświęcenia, przyznając jej w zamian nowe znaczenie, które zawierał w sobie symbol Matki-Polki (Szymanik, 2014, s. 89).

$\mathrm{Na}$ kartach swojej powieści jej młoda autorka raz po raz eksponowała szczególną rolę matki w wychowaniu dzieci, gorąco zalecając, aby polskie matki samodzielnie opiekowały się swoimi dziećmi. Jak bowiem wiadomo, w czasach Tańskiej w określonych sferach wcale nie było to praktyką powszechną. Zresztą, sama przyszła autorka Pamiątki po dobrej matce niemal przez dekadę wychowywała się poza domem, u powinowatej ojca, starościny wyszogrodzkiej Anieli ze Świdzińskich Szymanowskiej $^{12}$. Młoda autorka szczególnie gorąco przestrzegała rodziców, aby do opieki nad swoimi dziećmi nie zatrudniali opiekunek obcego pochodzenia, nieznających narodowych tradycji i niepojmujaccych „narodowego ducha”. To matki (a nie obce opiekunki) od początku życia swoich dzieci miały mieć bezpośredni wpływ na ich wychowanie w duchu narodowym (por. Stawiak-Ososińska, 2003, s. 291). Klementyna Tańska, kreśląc model wychowania polskich kobiet, zdecydowanie wystąpiła przeciw faworyzowaniu francuskiego stylu wychowania, eksponując potrzebę wychowania dzieci w duchu narodowym.

W przekonaniu Tańskiej w trudnych czasach zaborów na straży polskich rodzin miały stanąć kobiety, bowiem mężczyźni - ze względu na sytuację polityczną - mieli przypisane inne role (np. społeczne,

11 Pisał o tym szeroko Adam Mickiewicz. Zob. Mickiewicz, 1952, s. 63-64.

12 Aniela Szymanowska wychowywała małoletnią Klementynę Tańską w atmosferze „konserwatywno-tradycyjnej, równocześnie jednak w kulcie języka i romansowej literatury francuskiej”. Dopiero w wieku trzynastu lat Klementyna dołączyła do matki (zamieszkując po śmierci ojca razem z nią i swoimi siostrami w Warszawie). Zob. Ciechanowska, 1961, s. 573-576. 
niepodległościowe). To właśnie we wspomnianym obszarze Tańska widziała szczególnie ważną rolę Polek, a nawet ich swoistą misję narodową, nie do przecenienia w okresie niewoli. Jednocześnie młoda autorka doskonale zdawała sobie sprawę, że do tej ważnej roli kobiety musiały zostać odpowiednio przygotowane. Przede wszystkim musiały być one w pełni świadome narodowo (czego nie dawały im współczesne pensje, propagujące głównie język francuski i kulturę francuską), wyposażone w niezbędne narzędzia intelektualne (znajomość polskiego języka, historii literatury, kultury) oraz posiadać określone predyspozycje moralne, a także konkretne umiejętności praktyczne.

Wizerunek kobiety (oraz relacji kobiety i mężczyzny) wyłaniający się z pism Klementyny z Tańskich Hoffmanowej był bardzo mocno zakorzeniony w tradycji chrześcijańskiej oraz zgodny z dominującym ówcześnie na ziemiach polskich patriarchalnym systemem społecznym, eksponującym naturalny dualizm płci oraz będący jego wynikiem podział ról społecznych. Swoim młodym czytelniczkom Tańska raz po raz przypominała, że „mężczyzn Stwórca do rządzenia i starszeństwa przeznaczył”, zaś kobiety do „uległości” i do „posłuszeństwa” (Hoffmanowa, 1819, s. 18). W Pamiatce po dobrej matce jej autorka uczyła swoje czytelniczki: „inne zupełnie nasze, inne mężczyzn powołanie: we wszystkim też różnimy się od nich” (Hoffmanowa, 1819, s. 61). W innym miejscu przestrzegała: „ach, jak okropnie (...) błądzi kobieta, która więcej chce być nad to co ją Bóg przeznaczyl” (Hoffmanowa, 1819, s. 26).

Wykluczając jakikolwiek rodzaj buntu w tym względzie, Tańska zalecała dziewczętom swoiste „wdrażanie” się w swoją rolę już od najmłodszych lat, pisała tedy „ulegaj ojcu, mężowi, starszym, czyń ich wolę” (Hoffmanowa, 1819, s. 105). Pozostając w zgodzie z dominującym ówcześnie przekonaniem, iż podstawowym celem kobiet jest „życie domowe”, Tańska w Pamiatce po dobrej matce najwięcej uwagi poświęciła małżeństwu i macierzyństwu. „Małżeństwo jest wszystkiem dla kobiety, połową tego wszystkiego dla mężczyzny” - pisała Tańska na kartach swojej powieści i nie szczędziła czytelniczkom rad, jak utrzymać przywiązanie męża. Podstawową radą była uległość żony wobec męża (bowiem „niewiasta ulegać umiejąca na zawsze szczęśliwa i kochaną zostanie”) i bezgraniczna wyrozumiałość wobec małżonka. Przy tym jednak Tańska nie kryła, że małżeństwo może być także dla kobiety prawdziwym jarzmem („kajdanami”) i źródłem jej cierpień (pisała np.: „Małżeństwo nie jest tak szczęśliwym stanem jak więc wydają, tysięczne za sobą ciągnie kłopoty, i że żadna młoda osoba spieszyć się do niego nie powinna”) (Hoffmanowa, 1819, s. 105).

Podkreślając konieczność pracy nad sobą młodych Polek, dla dobra własnego i ich rodzin, Tańska przekonywała swoje czytelniczki, iż 
„cierpliwość, słodycz, uleganie, jednostajność humoru nieodzownie potrzebne są każdej kobiecie” (Hoffmanowa, 1819, s. 195). Bowiem „Bóg stworzył kobietę: łagodzić, miękczyć, uszczęśliwiać śmiałego towarzysza” (Hoffmanowa, 1819, s. 7-8). Jako najskuteczniejszy sposób „przywiązania sobie na zawsze męża” zalecała więc posłuszeństwo i bezustanne zabieganie o względy męża: „Poznawaj najdrobniejsze gusta jego, okazuj mu tysięczne względy, otaczaj go pieczołowitym staraniem" - radziła autorka młodym żonom i kandydatkom na nie na kartach Pamiatki po dobrej matce (Hoffmanowa, 1819, s. 162). Dbałość o męża i jego potrzeby dla ówczesnej kobiety były priorytetem, bowiem, jak piszą historycy, „wszystko, z czego człowiek zwykł być dumny: stanowisko w świecie, poważanie, odpowiednią sytuację społeczną kobieta zyskiwała wyłącznie dzięki pośrednictwu mężczyzny” (Szymczak-Hoff, 1982, s. 94).

Przedstawiony w powieści Tańskiej wzór kobiety poddanej i uległej wobec mężczyzny respektował realia społeczno-obyczajowe i wychowawczo-edukacyjne początku XIX w. oraz obowiązujące ówcześnie normy prawne. W czasach kiedy Tańska pisała swoją powieść, sytuacja kobiet na ziemiach polskich zależała bowiem przede wszystkim od uregulowań prawnych, funkcjonujących w każdym z państw zaborczych (por. Bednarz-Grzybek, 2010, s. 25). Istniały jednak pewne cechy wspólne ustawodawstwa odnoszącego się do kobiet. We wszystkich trzech państwach kobiety nie posiadały bowiem praw wyborczych (przez cały wiek XIX), nie miały też jednakowych z mężczyznami praw dysponowania majątkiem. Szczególnie w chwili zawarcia małżeństwa prawa majątkowe kobiet ulegały ograniczeniu na rzecz męża (por. Bogucka, 2005, s. 243). Co istotne, sama Tańska, akceptując ówczesne ograniczenia prawne w stosunku do kobiet i nie buntując się przeciwko nim, starała się pokazać swoim czytelniczkom pozytywne strony pozostawania przez kobiety osobami „drugiego rzędu”. Podkreślała tedy rolę współczesnych sobie kobiet, pisząc, iż w ich ręce ,złożone zostały (...) zarzewia wiary, cnót domowych i obywatelskich” (Hoffmanowa, 1819, s. 21).

Klementyna Tańska w Pamiątce po dobrej matce szczególną uwagę zwróciła na konieczność kształcenia kobiet, ale kształcenia odpowiedniego, zgodnego z powołaniem przypisanym jej przez Boga. Propagując określony wzór kobiecości mocno oparty na wartościach religijnych, Tańska miała na celu stworzenie w ten sposób bazy, stanowiącej pomoc dla polskich rodzin czasów niewoli. I temu nadrzędnemu celowi podporządkowała wolność indywidualną polskich kobiet.

Pozostając w zgodzie z ówczesnymi przekonaniami, autorka Pamiątki po dobrej matce na każdym kroku eksponowała konieczność trzymania się przez mężczyzn i kobiety określonych ról społecznych, uzasadniając to odwiecznym (Bożym) porządkiem świata. W związku z tym polska 
autorka (podobnie jak ponad pół wieku wcześniej Jean Jakub Rousseau w Emilu, wyd. 1762) twierdziła, że kobieta i mężczyzna nie powinni posiadać takiego samego wychowania i wykształcenia. Owszem, podkreślała ona wartość wiedzy w życiu kobiety, jednak przede wszystkim wiedzy „zgodnej z podstawowym przeznaczeniem kobiet” jako żon i matek, czyli wiedzy „użytecznej”, a przy tym „nie nazbyt głębokiej”. Autorka raz po raz przestrzegała swoje uczennice przed niebezpiecznym dla nich nadmiernym „zgłębianiem” nauk, które, jak wówczas sądzono, stwarza śmiesznych i szkodliwych „półmędrków niewieścich”. W Pamiątce po dobrej matce Tańska pisała:

Nigdy nie chwalę kobiecie, kiedy się oddaje wysokim naukom, kiedy się uczy łacińskiego, greckiego, hebrajskiego języka, doświadczenia robi w fizyce, chemii i nad algebrą lub matematyką głowę sobie łamie. Umieć uszczęśliwić małżonka, uprzyjemnić jego życie, wychować dobrze dzieci (...) to jest system naukowy dla kobiety (...) a matematyki niech ma tylko tyle aby z prostej nie zboczyła linii (Hoffmanowa, 1819, s. 147).

Tego rodzaju postulaty były zresztą zgodne z ówczesnymi wytycznymi rządowymi dotyczącymi kształcenia kobiet. Również w Instytucie Rządowym Guwernantek, gdzie wykładała Tańska, nauczyciele zostali zobowiązani określonymi przepisami do przekazywania uczennicom jedynie wiadomości podstawowych. W dokumencie z 22 listopada $1826 \mathrm{r}$. pt. Urzadzenie Instytutu Rządowego Wychowania Ptci Żeńskiej (Dział III: Osoby uczące, art. 20) znalazł się zapis:

Wszyscy Nauczyciele w wykładzie nauk przez siebie dawanych, nie będą się zapuszczać w głębokie badania, w rozwijaniu w całej obszerności zasad każdej myśli, bo to przechodzi powołanie kobiet. Mając na uwadze przyszłe przeznaczenie swoich uczennic, tudzież ogólne powołanie płci żeńskiej, do potrzeb tego podwójnego stanu, wykład swój zastosują, ograniczając się istotnie tylko potrzebnymi wiadomościami. Obok tego obowiązkiem będzie Nauczycieli zaszczepiać i umacniać uczucie skromności i wstrzemięźliwości naukowej, na szczerem i wewnętrznem przeświadczeniu zasadzonej, pomnąc, że jeżeli zarozumiałość w zawodzie naukowym niemiłą jest w mężczyźnie, jakże odrażającą musi być w kobiecie? (Urządzenie Instytutu Rządowego, 1868, s. 367).

Do nauk bezpiecznych dla kobiet (chociaż nie w nadmiarze) Tańska zaliczyła natomiast: religię, naukę moralności oraz historię i literaturę narodową. W sposób szczególny Tańska podkreślała konieczność posiadania przez Polki niezbędnych „umiejętności praktycznych”, do których zaliczała: wszystkie prace domowe, robótki kobiece, zarządzanie służbą, 
prowadzenie ksiag gospodarczych oraz odpowiednie zachowanie się w towarzystwie. Do umiejętności szczególnie użytecznych, bez których żadna Polka „nowych czasów” obejść się nie może, zaliczała Tańska także rachunki, uznając je za bardzo przydatne w prowadzeniu gospodarstwa. Dbałość o finanse własne i rodziny, połączoną ze znajomością rachunków, a także z pracowitością, gospodarnością i oszczędnością Tańska zalecała wszystkim swoim rodaczkom żyjącym w trudnych czasach niewoli politycznej - niewykluczone, że był pewien wpływ protestanckiego pierwowzoru Pamiatki po dobrej matce.

$\mathrm{Na}$ marginesie warto dodać, że skrupulatność i zaradność ekonomiczną, która zdaniem autorki powinna stać się udziałem ogółu polskich kobiet czasów zaborów, widać w życiu prywatnym samej Tańskiej, będącej jedną z pierwszych Polek zarabiających na swoje utrzymanie (własną pracą pisarską i pedagogiczną). Na kartach pozostawionych przez Tańską Pamiętników ich autorka jawi się jako kobieta niezależna finansowo, przedsiębiorcza i dobrze zorganizowana (Hoffmanowa, 1849b, s. 113114, 157-158).

Klementyna z Tańskich, chociaż, jak już wspomniano, propagowała wzór kobiety pokornej, skromnej, łagodnej, to w jej przekonaniu jednocześnie miała to być również kobieta posiadająca określone wykształcenie, świadoma narodowo obywatelka, osoba zaradna, mająca odpowiednie umiejętności praktyczne, potrafiąca w razie potrzeby zadbać finansowo o siebie i swoich bliskich (Hoffmanowa, 1849b, s. 46-47). Propagowany przez Tańską wzór kobiety i model kobiecości kładł bowiem swoisty nacisk na wyrobienie w kobietach odporności na przeciwności losu - niezbędnej w polskich realiach okresu niewoli - oraz umiejętność praktycznego radzenia sobie $\mathrm{z}$ nimi.

Nie bez przyczyny na kartach Pamiatki po dobrej matce jej autorka, zwracając uwagę swoim czytelniczkom na trudną rzeczywistość, w której przyszło im żyć (,żyjemy w czasach, gdzie największe odmiany nie wydają się nadzwyczajne”), namawiała je do nabywania odpowiednich umiejętności praktycznych, które w razie przeciwności losu (np. politycznych oraz związanych $z$ nimi perturbacji rodzinnych) pozwolą kobietom własną pracą utrzymać siebie i dzieci. „Z rąk pracy utrzymać się można: a wszędzie (...) pokupniejsze hafty i szycia, jak niedoskonały rysunek lub nuty (...)” - pisała na kartach swojej powieści (Hoffmanowa, 1819, s. 46-47).

Współcześni socjologowie podkreślają, że to właśnie okres niewoli politycznej wytworzył funkcjonujący do dziś w sferze postaw i zachowań „społeczny genotyp wzoru kobiety jako osoby, która potrafi sprostać najtrudniejszym wymaganiom stawianym przez rzeczywistość społeczną” (por. Titkow, 1995, s. 11). 


\section{Społeczna żywotność wzorów kobiecych spopularyzowanych przez Tańską}

Mimo krytyki programu Tańskiej i propagowanych przez nią kobiecych wzorów osobowych, obserwowanej na większą skalę w drugiej połowie wieku XIX, a zwłaszcza po roku 1864, kiedy na ziemiach polskich rozwinęły się idee emancypacji i równouprawnienia kobiet, w gruncie rzeczy ideały autorki Pamiątki po dobrej matce były żywe wśród społeczeństwa polskiego (a przynajmniej w pewnych jego kręgach) przez cały wiek XIX. Swoją drogą, powieść Tańskiej musiała być na tyle popularna nawet $\mathrm{w}$ ostatnich dekadach XIX stulecia, a wskazania tam zawarte na tyle uznane i żywotne, że wydawała się ona warta uwagi oraz żarliwej polemiki jeszcze w roku 1875, czyli aż 56 lat po jej pierwszym wydaniu! Wspomniana polemika wyszła spod pióra pisarki związanej z popowstaniowym ruchem emancypacyjnym, Narcyzy Żmichowskiej - dawnej uczennicy Klementyny Tańskiej (Żmichowska, 1876). Żmichowska, eksponując anachroniczność wskazówek Tańskiej w kontekście nowych realiów połowy lat 70. XIX stulecia, pisała:

(...) jej przepisy nie wystarczają na zaspokojenie twardych wymagań dzisiejszej współczesności (...) Ze wszystkich stron już nowe teorie, nowe ideały, potrzeby nowe przeciskają się do nas rozmaitymi tytułami: emancypacji, równouprawnienia, wolności kobiet (Żmichowska, 1876, s. 208-209).

Jednak w gruncie rzeczy owe „nowe teorie, nowe ideały” nie zgasiły zupełnie gwiazdy Tańskiej. Jeszcze w latach 80. XIX w. znana polska pisarka pozytywistyczna Eliza Orzeszkowa w artykule $O$ kobiecie polskiej (1882) pisała, że rady Tańskiej ,aż do roku 1830 były rodzajem ewangelii kobiety polskiej (...) i czynność, którą przez kilkadziesiąt lat pełniły, wielce obfitą była w następstwa” (Orzeszkowa, 2005, s. 612).

Wspomnianych przez Orzeszkową „następstw” społecznych modelu wychowania kobiet polskich i związanych z nim wzorów osobowych spopularyzowanych przez Klementynę z Tańskich Hoffmanową oraz ich żywotności w zasadzie przez cały wiek XIX dowodzą choćby ówczesne zapiski pamiętnikarskie ${ }^{13}$.

13 Zob. m.in.: Kunachowiczowa, 1980, s. 302; [Pruszakowa S. Duchińska], 1956, t. 1-2; Boberska, Lwów 1871; Papi,1905. 


\section{Zakończenie}

We współczesnych realiach, kiedy, jak wiadomo, równość kobiet i mężczyzn gwarantuje prawo (konstytucja) ${ }^{14}$, w czasach wyczulenia na wszelkie przejawy dyskryminacji (prawdziwe lub urojone) oraz ograniczania wolności kobiet, bardzo łatwo ulec pokusie krytyki poglądów Klementyny z Tańskich Hoffmanowej oraz propagowanych przez nią kobiecych wzorów osobowych. Nic zatem dziwnego, iż zdecydowanie nielicznym współczesnym czytelnikom dziełka Tańskiej, niezaznajomionym w wystarczającym stopniu z jego dziewiętnastowiecznym kontekstem (niebędącym historykami literatury/kultury/idei), w istocie „trudno jest zrozumieć (...) zachwyty nad tą książką" jej dawnych odbiorców ${ }^{15}$. W efekcie, jeśli aktualnie temat Pamiattki po dobrej matce w ogóle pojawia się poza dyskursem o charakterze stricte naukowym, to na ogół powieść ta i koncepcje jej autorki przywoływane są jako przykład anachroniczny, kontrowersyjny, a przy tym... humorystyczny (Wróbel, 2014).

Tymczasem, co oczywiste, na poglądy autorki bestselleru sprzed dwóch wieków należy patrzeć w perspektywie historycznej, w ścisłym połączeniu z szerokim kontekstem dziewiętnastowiecznym (dziejowym, społecznym, prawnym, kulturowym), biorąc pod uwagę trudną i złożoną sytuację społeczeństwa polskiego w okresie niewoli politycznej oraz uświadomioną już w pierwszych latach zaborów potrzebę ochrony tożsamości narodowej. Tę właśnie swoistą misję dziejową Klementyna z Tańskich przypisała polskim kobietom jako żonom, matkom i obywatelkom: kobietom odpowiednio ukształtowanym moralnie i wykształconym adekwatnie do ówczesnych możliwości i potrzeb.

Jak już wspomniano, chociaż jej program zawierał pewne elementy nowatorskie, to celowo był on bardzo ostrożny i tradycyjny, akceptujący aktualne regulacje i ograniczenia prawne oraz wskazania wynikające z religii chrześcijańskiej, jak również polskie obyczaje i przyzwyczajenia społeczne (m.in. patriarchalizm). Młoda autorka posiadała bowiem świadomość, że tylko tego rodzaju program miał szansę zostać zaakceptowany społecznie i zrealizowany w tamtym czasie. W ówczesnych polskich realiach prawno-obyczajowych nie było miejsca na większe ustępstwa. $\mathrm{Z}$ tego względu autorka $\mathrm{z}$ pełnym wyczuciem dozowała nowości, subtelnie implantując je do warunków polskich. Nawet niechętna Tańskiej

14 Konstytucja Rzeczypospolitej Polskiej z dnia 2 kwietnia 1997 r., Dz. U. nr 78 z 1997. (Art. 32): „Wszyscy są wobec prawa równi. (Art. 33): „Kobieta i mężczyzna w Rzeczypospolitej Polskiej mają równe prawa w życiu rodzinnym, politycznym, społecznym i gospodarczym”.

15 https://lubimyczytac.pl/ksiazka/107449/pamiatka-po-dobrej-matce-czyli-ostatnie-jej-rady-dla-corki (dostęp: 16.10.2020). 
wspomniana już Narcyza Żmichowska przyznawała, iż jej dawna nauczycielka „z wrodzonym sobie darem wdzięku umiała w obieg puścić najnowsze swej epoki wyobrażenia pod osłoną najstarożytniejszych zasad” (por. Żmichowska, 1876).

Otwarte pozostaje natomiast pytanie, czy (oraz w jakim stopniu) upowszechniane przez Klementynę z Tańskich poglądy na kobiety oraz ich rolę były bliskie jej samej? Tego rodzaju pytanie wcale nie jest bezzasadne. Biorąc pod uwagę propagowane w twórczości Tańskiej wzory kobiece oraz jej własną aktywność zawodową, wyraźnie bowiem widać pewien rozdźwięk pomiędzy teorią rozpowszechnianą przez Tańską a praktyką jej własnego życia aktywnego i niezależnego - autorka nie bez powodu bywa przecież nazywana „pierwszą kobietą niezależną” na gruncie polskim ${ }^{16}$.

W moim przekonaniu, propagowanie przez Tańską wśród ówczesnego społeczeństwa polskiego ściśle określonego wzoru kobiety Polki było jej świadomym wyborem dokonanym w perspektywie społecznej. Sama Klementyna Tańska w istocie prezentowała już bowiem zdecydowanie nowy typ kobiety: wolnej (wyszła za mąż dopiero w wieku 31 lat, nie miała dzieci ${ }^{17}$ ), wykształconej, aktywnej zawodowo, zainteresowanej sprawami publicznymi, samodzielnej, niezależnej finansowo (dzięki własnej pracy), przedsiębiorczej (a przy tym głęboko religijnej, zdeklarowanej patriotki). Patrząc jednak na propagowany przez nią wzór kobiety i model kobiecości, widać, że nie wszystkie z wyżej wymienionych cech autorka Pamiątki po dobrej matce uważała za pożądane dla ogółu polskich kobiet. Pozostawiła je zatem dla siebie.

Natomiast dla ogółu Polek czasów niewoli Klementyna z Tańskich Hoffmanowa stworzyła i spopularyzowała inny, zdecydowanie bardziej tradycyjny wzór kobiety: realizującej się przede wszystkim na płaszczyźnie domowo-rodzinnej, zapobiegliwej gospodyni, oddanej żony, matki, świadomej obywatelki - wychowującej dzieci w duchu narodowym. Taki bowiem w jej przekonaniu był najbardziej pożyteczny, a przy tym akceptowalny społecznie, wzór osobowy polskiej kobiety na trudne czasy niewoli politycznej.

16 Klementyna Hoffmanowa - pierwsza kobieta niezależna. Pozyskano z: www.polskieradio. pl/39/156/Artykul/1670545,Klementyna-Hoffmanowa-\%E2\%80\%93-pierwsza-kobieta-niezalezna (dostęp: 10.10.2020).

17 Niewykluczone, że wpływ na to miała nabyta przez Tańską w dzieciństwie poważna wada postawy, która tej mało posażnej pannie utrudniała zamążpójście. Jednak we wspomnieniach Tańskiej pojawiają się także inne argumenty: 22-letnia autorka pisała, że „nie ma ochoty išć za mąż" (1820) głównie z obawy przed tym, iż małżeństwo odciągnie ją od dotychczasowych zajęć pisarskich i pedagogicznych, które były jej powołaniem. 


\section{BIBLIOGRAFIA}

Askenazy, S. (1918-1919). Napoleon i Polska, t. 1-3. Warszawa - Kraków: Towarzystwo Wydawnicze w Warszawie.

Bednarz-Grzybek, R. (2010). Emancypantka i patriotka: wizerunek kobiety przetomu XIX i XX wieku w czasopismach Królestwa Polskiego. Lublin: Wydawnictwo Uniwersytetu Marii Curie-Skłodowskiej w Lublinie.

Boberska, F. (z Wasilewskich). (1871). Klementyna z Tanskich Hoffmanowa: odczyt Felicji Wasilewskiej z dnia 23 kwietnia 1871. Lwów.

Bogucka, M. (2005). Gorsza pteć. Kobieta w dziejach Europy od antyku po wiek XXI. Warszawa: Wydawnictwo Trio.

Bołdyrew, A. (2008). Matka i dziecko w rodzinie polskiej: ewolucja modelu zycia rodzinnego w latach 1795-1918. Warszawa: Neriton.

Brodziński, K. (1819). „Pamiątka po dobrej matce przez młodą Polkę”. Pamiętnik Warszawski, t. 15, listopad, 311-319.

Chwalba, A. (2008). Historia Polski 1795-1918. Kraków: Wydawnictwo Literackie.

Chmielowski, P. (1898). Klementyna z Tańskich Hoffmanowa. Zarys biograficzno-pedagogiczny przez Piotra Chmielowskiego. Petersburg: Nakładem Kazimierza Grendyszyńskiego.

Chmielowski, P. (1901). Klementyna z Tańskich Hoffmanowa (1798-1845). W: Album biograficznie zastuzonych Polaków i Polek XIX wieku, t. 1. Warszawa: Wydane staraniem i nakładem Maryi Chełmońskiej, 170-172.

Ciechanowska, Z. (1960-1961). Biogram: Hoffmanowa z Tańskich Klementyna (1798-1845). W: Polski Stownik Biograficzny, t. IX. Wrocław: Polska Akademia Umiejętności, Zakład Narodowy im. Ossolińskich Wydawnictwo Polskiej Akademii Nauk, 573-576.

Czubaty, J. (2005). Zasada „dwóch sumieñ”. Normy postepowania i granice kompromisu politycznego Polaków w sytuacjach wyboru (1795-1815). Warszawa: Neriton.

Dąbrowska, J.E. (2008). Klementyna. Rzecz o Klementynie z Tańskich Hoffmanowej. Białystok: Trans Humana.

Dębicki, L.Z. (1887). Putawy (1762-1830). Monografia z życia towarzyskiego, politycznego i literackiego, t. 2. Lwów: Nakład Księgarni Gubrynowicza i Schmidta.

Glatz, J. (1808). Rosaliens Vermächtnis an ihre Tochter Amanda; oder Wörte einer guten Mutter an den Geist und das Herz ihrer Tochter. Ein Bildungsbuch für Deutschlands Töchter. Leipzig: Friedrich August Leo.

Guseva, O. (2019). Proizvedenija Klementiny Hoffmanovoj iz roda Tan'skih v russkih perevodah. Acta Universitatis Wratislaviensis. Slavica Wratislaviensia, t. 169, nr 3890, 11-22. DOI: 10.19195/0137-1150.169.2. 
Kunachowiczowa, H. (z Kadłubowskich). (1980). Dziennik z lat 1856-1860. W: B. Łopuszański i I. Homola (red.), Kapitan i dwie panny krakowskie pamiętniki z dziewiętnastego wieku. Kraków: Wydawnictwo Literackie.

Hoffmanowa, K. (1819). Pamiattka po dobrej matce czyli jej ostatnie rady dla córki przez mtoda Polke. Warszawa: Nakładem G. Sennewalda.

Hoffmanowa, K. (1822-1824). Amelia matka. Dzieto za dalszy ciag „Pamiatti po dobrej matce" stuzyć mogace, przez tęż samq Autorke, t. 1-3. Warszawa: Drukarnia Łątkiewicza.

Hoffmanowa, K. (1824-1826). Listy matki o wychowaniu córek swoich. W: K. Hoffmanowa, Rozrywki dla Dzieci. Warszawa.

Hoffmanowa, K. (1849a). O powinnościach kobiet. Berlin.

Hoffmanowa, K. (1849b). Pamiętniki. W: Pisma pośmiertne Klementyny z Tańskich Hoffmanowej, t. 1. Berlin: Księgarnia B. Behra.

Jedlicki, J. (2002). Jakiej cywilizacji Polacy potrzebuja. Studia z dziejów idei i wyobrazni XIX wieku. Warszawa: WAB, CiS.

Kamionkowa, J. (1970). Życie literackie $w$ Polsce $w$ pierwszej potowie XIX w. Studia. Warszawa: Państwowy Instytut Wydawniczy.

Kieniewicz, S., Zahorski, A. i Zajewski, W. (1992). Trzy powstania narodowekościuszkowskie, listopadowe, styczniowe. Warszawa: Książka i Wiedza.

Konstytucja Rzeczypospolitej Polskiej z dnia 2 kwietnia 1997 r., Dz. U. nr 78 z 1997.

Kotowa, I. (1925/26). Pierwsze dzieło Klementyny Tańskiej. Pamiętnik Literacki: czasopismo kwartalne poświęcone historii i krytyce literatury polskiej, t. 22/23, nr 1/4, 202-220.

Koźmian, K. (1972). Pamiętniki, t. 1-3. Wrocław: Ossolineum.

Kraushar, A. (1901). Kandydatura panny Klementyny Tańskiej do Byłego Królewskiego Towarzystwa Przyjaciół Nauk. Tygodnik Ilustrowany, nr 49.

Kukiel, M. (1912). Dzieje oręża polskiego w epoce napoleońskiej 1795-1815. Poznań: Zdzisław Rzepecki i Ska.

Libera, L. (1982). „Rozrywki dla dzieci” jako czasopismo narodowe. Kwartalnik Historii Prasy Polskiej, t. 21, nr 1, 5-16.

Mączak, A. (1993). Jedyna i nieporównywalna? Kwestia odrębności Rzeczypospolitej w Europie XVI-XVIII wieku. Kwartalnik Historyczny, R. 100, nr 4, 121-136.

Miąso, J. (1966). Szkolnictwo zawodowe w Królestwie Polskim w latach 18151915. Wrocław: Ossolineum.

Mickiewicz, A. (1952). O duchu narodowym. W: A. Mickiewicz, Dzieła. T. 6, cz. 2. Kraków: Wydanie Narodowe, 63-64.

Orzeszkowa, E. (2005). O kobiecie polskiej [studium dla angielskiej zbiorowej książki Theodore'a Stantona o kobietach w Europie]. W: E. Orzeszkowa, Publicystyka społeczna, t. 1. Kraków: Wydawnictwo Literackie.

Ossowska, M. (2000). Ethos rycerski i jego odmiany. Warszawa: Wydawnictwo Naukowe PWN. 
Ossowska, M. (1992). Wzór demokraty. Lublin: Daimonion.

Ossowski, S. (2000). Z zagadnień psychologii spotecznej. Warszawa: Wydawnictwo Naukowe PWN.

Papi, J. (1905). Klementyna. Powieść dla dorastających panien osnuta na tle życia Klementyny z Tanskich Hoffmanowej. Warszawa: Gebethner i Wolff; Kraków: G. Gebethner i Sp.

Pruszakowa [Duchińska], S. (1956). Rozrywki dla mtodocianego wieku: dzieto zbiorowe $w$ tomach 5 obejmujace powieści, podróze, literature i rozmaitości, t. 1-2. Warszawa: Drukarnia J. Jaworskiego.

Rynio, A. (2015). hasło: „Wzór osobowy”. W: K. Chałas i A. Maj (red.), Encyklopedia aksjologii pedagogicznej. Radom: Polskie Wydawnictwo Encyklopedyczne POLWEN, 1459-1465.

Stawiak-Ososińska, M. (2003).Wychowanie domowe dziewcząt w świetle poglądów publicystów pierwszej połowy XIX wieku w Królestwie Polskim (rola i zadania matki w domowym wychowaniu córek). Studia Pedagogiczne. Problemy Spoteczne, Edukacyjne i Artystyczne, t. 14, 285-300.

Suchodolski, B. (1977). Wstęp. W: J. Michalski (red.), Historia nauki polskiej, t. 3: 1795-1862. Wrocław - Warszawa - Kraków - Gdańsk: Ossolineum.

Świderska-Włodarczyk, U. (2016). Szlachecki wzorzec żołnierza Rzeczypospolitej XVI i XVII wieku (w świetle nowej definicji pisanej na użytek badań historycznych). Kultura i Historia, nr 29, bez numerów stron.

Szymanik, E. (2014). Równość płci. Aspekty historyczno-społeczne i prawne. Seminare. Poszukiwania naukowe, t. 35, nr 4, 83-94.

Szymczak-Hoff, J. (1982). Drukowane kodeksy obyczajowe na ziemiach polskich w XIX w. Studium źódtoznawcze. Rzeszów: Wydawnictwo Uczelniane WSP.

Stankiewicz-Kopeć, M. (2016). Poglądy Klementyny z Tańskich Hoffmanowej 1798-1845 w refleksji uczennic. Studia Paedagogica Ignatiana, t. 19, nr 3, 99-121. DOI: 10.12775/SPI.2016.3.005.

Stankiewicz-Kopeć, M. (2018). Miasto i cywilizacja w kontekście sporów modernizacyjnych $w$ pismiennictwie polskim lat 1800-1830. Studia. Kraków: Wydawnictwo Naukowe Akademii Ignatianum w Krakowie.

Tazbir, J. (1979). Pochwała „nieudacznika” i nagana kariery w literaturze polskiej. W: J. Tazbir, Spotkania z historia. Warszawa: Wydawnictwo Iskry.

Titkow, A. (1995). Kobiety pod presją? Proces kształtowania się tożsamości. W: A. Titkow i H. Domański (red.), Co to znaczy być kobieta w Polsce. Warszawa: Instytut Filozofii i Socjologii PAN.

Urządzenie Instytutu Rządowego Wychowania Płci Żeńskiej (art. 20). W: Zbiór przepisów administracyjnych Królestwa Polskiego. Wydziat Oświecenia, t. 5: Zakłady naukowe średnie. Warszawa 1868.

Winiarz, A. (2002). Szkolnictwo Księstwa Warszawskiego i Królestwa Polskiego (1807-1831). Lublin: Uniwersytet Marii Curie-Skłodowskiej. 
Winiarz, A. (2000). Wpływ kobiety-matki na życie polskiej rodziny ziemiańskiej doby niewoli narodowej (1795-1918). W: K. Jakubiak (red.), Partnerka, matka, opiekunka. Status kobiety $w$ dziejach nowozytnych od XVI do XX wieku. Bydgoszcz: Wydawnictwa Uczelniane Wyższej Szkoły Pedagogicznej.

Wróbel, O. (2014). Tej dobrej matce juz dziękujemy - lektura Klementyny Hoffmanowej dwieście lat pózniej. Pozyskano z: https://kobieta.gazeta. pl/kobieta_ekstra/1,155242,16544888,tej-dobrej-matce-juz-dziekujemy-lektura-klementyny-hoffmanowej.html (dostęp: 27.11.2020).

Wysocka, E. (2008). Hasło: „Wzór osobowy”. W: T. Pilch (red.), Encyklopedia pedagogiczna XXI wieku, t. VII. Warszawa: Wydawnictwo Akademickie Zak.

Zamorski, B. (1881). W pięćdziesiąta rocznice powstania r. 1830: studium dziejowe przez Bronistawa Zamorskiego. Lwów: K. Łukaszewicz.

Zdrada, J. (2020). Historia Polski 1795-1914. Warszawa: Wydawnictwo Naukowe PWN.

Żmichowska, N. (1876). Słowo przedwstępne do dzieł dydaktycznych pani Hoffmanowej. W: N. Żmichowska (red.), Dzieta Klementyny z Tańskich Hoffmanowej, t. 8. Warszawa: Spółka Wydawnicza Księgarzy.

Żołądź-Strzelczyk, D. i Jamrożek, W. (2001). Studia z dziejów edukacji kobiet na ziemiach polskich. Poznań: Agencja Wydawniczo-Poligraficzna Bajt.

Monika Stankiewicz-Kopeć - dr hab., prof. AIK, absolwentka polonistyki na Uniwersytecie Jagiellońskim, pracownik Instytutu Kulturoznawstwa Akademii Ignatianum w Krakowie. Zajmuje się literaturą i kulturą XIX wieku. 